\title{
Leucaena leucocephala leachate compromised membrane integrity, respiration and antioxidative defence of water hyacinth leaf tissues
}

Tsun-Thai Chai ${ }^{1,2^{*}}$, Keng-Fei Ooh ${ }^{1}$, Pei-Wan Ooi ${ }^{1}$, Pei-Sing Chue ${ }^{1}$ and Fai-Chu Wong ${ }^{1,2}$

\begin{abstract}
Background: Water hyacinth is an invasive aquatic weed in many regions of the world. In this study, the bioherbicidal potential of allelopathic plant Leucaena leucocephala against water hyacinth was investigated using a leaf disc assay.

Results: L. leucocephala leachate enhanced electrolyte leakage from water hyacinth leaf discs in a concentrationdependent manner. Control experiments eliminated the possibilities that increased membrane permeability in the leachate-treated leaf discs was due to $\mathrm{pH}$ or osmotic effects of the leachate. Thus, the loss of membrane stability in the leachate-treated leaf discs was likely due to phytotoxins detected in the leachate, namely mimosine and phenolic constituents. Decline in tissue respiration was detected in leachate-treated water hyacinth leaf discs. This suggests that the L. leucocephala leachate may contain compounds which acted as respiratory inhibitors. Enhanced reactive oxygen species production coincided with inhibition of catalase and ascorbate peroxidase activities in the leachate-treated water hyacinth leaf tissues. The injurious effects of L. leucocephala leachate on water hyacinth leaf discs probably involved direct inhibition of antioxidant enzymes in addition to direct involvement of some allelochemicals in reactive oxygen species formation.
\end{abstract}

Conclusion: In summary, the toxic effects of L. leucocephala leachate on water hyacinth leaf discs likely lay in its ability to effectively compromise the membrane integrity, tissue respiration and antioxidant defence of the latter.

Keywords: Allelopathy; Ascorbate peroxidase; Catalase; Eichhornia crassipes; Electrolyte leakage; Leucaena leucocephala; Reactive oxygen species; Respiration

\section{Background}

Water hyacinth, Eichhornia crassipes (Mart.) Solms., is a floating aquatic plant native to Brazil. This species is an invasive weed in numerous freshwater ecosystems between $40^{\circ} \mathrm{N}$ and $40^{\circ} \mathrm{S}$ worldwide. Water hyacinth is fastgrowing and often forms dense mats on lakes, rivers, and waterways. Rapid, uncontrolled proliferation of water hyacinth adversely affects aquatic fauna and flora, impacting local biodiversity seriously. Colonisation of water bodies by water hyacinth poses problems to human activities, such as agriculture, recreation, power generation and transportation (Malik, 2007).

\footnotetext{
* Correspondence: chaitt@utar.edu.my

'Department of Chemical Science, Faculty of Science, Universiti Tunku Abdul Rahman, Kampar 31900, Malaysia

${ }^{2}$ Centre for Biodiversity Research, Universiti Tunku Abdul Rahman, Kampar 31900, Malaysia
}

\section{Springer}

(c) 2013 Chai et al.; licensee Springer. This is an Open Access article distributed under the terms of the Creative Commons Attribution License (http://creativecommons.org/licenses/by/2.0), which permits unrestricted use, distribution, and reproduction in any medium, provided the original work is properly cited. crude form, is a potentially valuable and sustainable approach in aquatic weed control (Szczepanski, 1977; Singh et al., 2003). Being natural plant products, allelochemicals are considered relatively eco-friendly as they are likely to degrade rapidly in the environment. The effectiveness of powders or extracts of allelopathic plants in inhibiting the growth of water hyacinth or killing the weed has been demonstrated (Pandey et al., 1993; Kathiresan, RM 2000; Saxena, 2000).

Leucaena leucocephala (Fabaceae) is an allelopathic tree species that is widespread in tropics and subtropics. Phytotoxic allelochemicals identified in the leaves of this legume species include mimosine and phenolic compounds, 
such as quercetin, p-hydroxycinnamic acid, protocatechuic acid, and gallic acid (Chou and Kuo, 1986). The physiological mechanisms of allelochemicals are complicated, and the outcome of an allelopathic interaction between two plants is often species-dependent (Iftikhar Hussain et al., 2008). Although the bioherbicidal activity of L. leucocephala on other terrestrial plants is well-established (Hong et al., 2003; John and Narwal, 2003), little is known about its effects on water hyacinth or other aquatic weeds.

Phenolic allelochemicals often adversely affect the membrane stability, respiration and oxidative status of plant cells (Einhellig, 2004; Weir et al., 2004; Gniazdowska and Bogatek, 2005; Li et al., 2010). Mimosine is known to inhibit the activities of iron-containing enzymes, some of which are important antioxidant enzymes in plant cells, e.g. catalase and peroxidase (Prasad and Subhashini, 1994; Andrade et al., 2008). Hence, there are two objectives in this study: first, to confirm whether L. leucocephala leachate is phytotoxic to water hyacinth, based on its effects on membrane integrity and tissue respiration; second, to confirm whether any phytotoxicity detected is mediated by suppression of antioxidative defence.

\section{Methods}

Preparation of Leucaena leucocephala leachates

Healthy mature leaves were collected from Leucaena leucocephala trees grown on the Kampar campus of Universiti Tunku Abdul Rahman. Leaflets were removed from the petioles, briefly washed and blotted dry. The leachates (5\%) used in this study were prepared by soaking $5 \mathrm{~g}$ of leaf material in $100 \mathrm{~mL}$ of autoclaved deionised water for $24 \mathrm{~h}$ and $48 \mathrm{~h}$, respectively. Incubation of the leaf material was carried out at $25^{\circ} \mathrm{C}$ in darkness on an orbital shaker (90 rpm). Using vacuumfiltration, leaf material was removed from the leachate solutions. Remaining particles were then removed by centrifugation at $8603 \times \mathrm{g}$ and $4^{\circ} \mathrm{C}$ for $10 \mathrm{~min}$. The supernatants obtained were stored at $-20^{\circ} \mathrm{C}$ until used.

\section{Experiment 1A: Effects of leachates on cellular membrane injury and tissue respiration}

Healthy water hyacinth plants with similar sizes were collected from a lake next to the campus at 9 am in the morning. The plants were carefully rinsed under running tap water to remove any debris, silt or small invertebrates that were present. The plants were then placed in a large plastic box filled with distilled water and allowed to acclimate for $24 \mathrm{~h}(12 \mathrm{~h} / 12 \mathrm{~h}$ light/dark $)$ at room temperature. The plants were illuminated at $100 \mu \mathrm{mol}$ photons $/ \mathrm{m}^{2} / \mathrm{s}$ Photosynthetically Active Radiation (PAR) during the light period. The next day, leaf discs $(0.7 \mathrm{~cm}$ diameter) were cut from uniform-looking leaves with a cork borer and then rinsed twice with autoclaved deionised water. Next, the leaf discs were vacuum- infiltrated (five cycles of $20 \mathrm{~s}$ ) with different dilutions of leachates $(0,0.1,0.5,1.0,2.5$, and $5.0 \%)$ and then transferred to Petri dishes each containing $20 \mathrm{~mL}$ of the same leachate solution, supplemented with $50 \mu \mathrm{L}$ of Tween-20. The Petri dishes were shaken on an orbital shaker (90 rpm) for $24 \mathrm{~h}$ at $25^{\circ} \mathrm{C}$ in darkness. At the end of the treatment, the leaf discs were rinsed with deionised water, blotted dry and used for analyses. Cellular membrane injury was assessed by measuring relative electrolyte leakage (REL) of the leaf discs as previously described (Kraus and Fletcher, 1994). Tissue respiration of the leaf discs was determined indirectly using 2,3,5-triphenyl tetrazolium chloride (TTC) as described in (Steponkus and Lanphear 1967). Reduction of TTC was expressed as absorbance per g dry weight (DW).

\section{Experiment 1B: Effects of leachate $\mathrm{pH}$ and osmotic potential on cellular membrane injury}

The $\mathrm{pH}$ and osmotic potential of L. leucocephala leachates $(0.1,0.5,1.0,2.5$ and 5.0\%) were determined and the effects of these two parameters on water hyacinth leaf discs were evaluated. The $\mathrm{pH}$ values of different dilutions of $24 \mathrm{~h}$ and $48 \mathrm{~h}$ leachates ranged between 6.9 and 7.5. To determine whether the $\mathrm{pH}$ of the leachates contributed to cellular membrane injury, leaf discs were treated as described above for Experiment 1A. Briefly, leaf discs were vacuum-infiltrated with deionised water pre-adjusted to $\mathrm{pH} 6.5,7.0,7.5$, and 8.0 with $0.1 \mathrm{M} \mathrm{NaOH}$ or $0.1 \mathrm{M} \mathrm{HCl}$. The leaf discs were then incubated in the same $\mathrm{pH}$ solutions for $24 \mathrm{~h}$. REL of the treated leaf discs was determined according to (Kraus and Fletcher 1994).

The osmotic potential of $24 \mathrm{~h}$ and $48 \mathrm{~h}$ leachates was estimated based on electrical conductivity (EC) measurements and the relation of osmotic potential $(\mathrm{MPa})=-0.036 \times \mathrm{EC}$, with $\mathrm{EC}$ in $\mathrm{dS} / \mathrm{m}$ (Bingham et al., 1987; Raviv and Blom, 2001). Electrical conductivity of the leachates was measured using a conductivity meter (Oakton Instruments, Vernon Hills, Illinois, USA). The osmotic potential of different dilutions of $24 \mathrm{~h}$ and $48 \mathrm{~h}$ leachates $(0.1,0.5,1.0,2.5$ and $5.0 \%)$ ranged between $-0.001 \mathrm{MPa}$ and $-0.036 \mathrm{MPa}$ as well as between -0.002 and $-0.079 \mathrm{MPa}$, respectively. To investigate possible effects of leachate osmotic potential on cellular membrane injury, leaf discs were treated as described above for Experiment 1A with mannitol solutions adjusted to the following osmotic potentials: $-0.05,-0.10$, and $-0.15 \mathrm{MPa}$. Mannitol concentrations corresponding to the aforementioned osmotic potential values were 2.532, 5.064, and $7.597 \mathrm{~g} / \mathrm{L}$, respectively, calculated from data published by (Sosa et al. 2005). Deionised water (osmotic potential taken as $0.0 \mathrm{MPa}$ ) was used as control. REL of the leaf discs was determined as previously described (Kraus and Fletcher, 1994). 


\section{Experiment 2: Detection of reactive oxygen species (ROS) production}

Water hyacinth leaf discs were treated with $48 \mathrm{~h}$ leachate at different concentrations $(0,1.0,2.5$ and 5.0\%) as described above for Experiment 1A. At the end of the $24 \mathrm{~h}$ treatment period, the leaf discs were used for detection of ROS accumulation. Hydrogen peroxide $\left(\mathrm{H}_{2} \mathrm{O}_{2}\right)$ content of the leaf tissues was determined as described in (Velikova et al. 2000) and expressed as $\mathrm{nmol} / \mathrm{g}$ fresh weight $(\mathrm{FW})$. Visualisation of superoxide $\left(\mathrm{O}_{2}{ }^{\bullet-}\right)$ production in $0,2.5$, and $5 \%$ leachate-treated leaf discs was carried out as described in (Dutilleul et al. 2003).

\section{Experiment 3: Assays of catalase (CAT) and ascorbate peroxidase (APX) activities}

Water hyacinth leaf discs were treated with $48 \mathrm{~h}$ leachate at different concentrations $(0,1.0,2.5$ and 5.0\%) as described above for Experiment 1A. CAT specific activity of the leachate-treated leaf tissues was determined as described in (Dhindsa et al. 1981) and expressed as $\mu \mathrm{mol} \mathrm{H}_{2} \mathrm{O}_{2}$ consumed $/ \mathrm{min} / \mathrm{mg}$ protein. APX specific activity of the leachate-treated water hyacinth leaf tissues was assayed according to (Nakano and Asada 1981) and expressed as nmol ascorbate oxidised/min/ mg protein. Protein concentration of enzyme extracts was determined according to (Bradford 1976) using bovine serum albumin as the standard.

\section{Experiment 4: Phytochemical analysis}

Total polyphenol and flavonoid contents of $24 \mathrm{~h}$ and $48 \mathrm{~h}$ leachates (5\%) were determined as previously described (Chai and Wong, 2012). Polyphenol contents were expressed in mg gallic acid equivalents $(\mathrm{GAE}) / \mathrm{mL}$, whereas flavonoid content was expressed in mg quercetin equivalents $(\mathrm{QE}) / \mathrm{mL}$. Total contents of hydroxycinnamic acid derivatives were determined as in (Matkowski et al. 2008) and expressed in $\mathrm{mg}$ caffeic acid equivalents (CAE)/mL. Mimosine contents of the leachates were determined by HPLC using a Gemini $5 \mathrm{u}$ C18 110A column (4.6 mm $\times 250 \mathrm{~mm}$, Phenomenex, Torrance, CA, USA). Mimosine was eluted with $0.2 \%$ orthophosphoric acid (v/v) in deionised water at a flow rate of $0.25 \mu \mathrm{L} / \mathrm{min}$ and was detected at a wavelength of $280 \mathrm{~nm}$ (Soedarjo and Borthakur, 1996). In our system, mimosine had a retention time of $6.3 \mathrm{~min}$.

\section{Statistical analysis}

Data reported are means \pm standard errors. Statistical analysis was performed using SAS (version 9.2). Data were analysed by the ANOVA test and means of significant differences were compared using Student's T-test at the 0.05 level of probability.

\section{Results}

Cellular membrane injury was evaluated in the $L$. leucocephala leachate-treated water hyacinth leaf discs based on REL measurements (Figure 1). Both of the $24 \mathrm{~h}$ and $48 \mathrm{~h}$ leachates caused cellular membrane injury, correlated with leachate concentrations. Notably, the $48 \mathrm{~h}$ leachate induced a more drastic increase in REL compared with 24 h leachate.

Water hyacinth leaf discs were treated with $\mathrm{pH}$ adjusted water $(\mathrm{pH} 6.5,7.0,7.5$ and 8.0) and mannitol solutions $(0.00,-0.05,-0.10$, and $-0.15 \mathrm{MPa})$ to assess possible effects of leachate $\mathrm{pH}$ and osmotic potential to REL detected in leachate-treated leaf discs. REL of leaf discs treated with $\mathrm{pH}$-adjusted water ranged between $4.9 \%$ and $5.3 \%$ (data not shown). REL of leaf discs treated with mannitol solutions ranged between $4.5 \%$ and $5.1 \%$ (data not shown). Neither $\mathrm{pH}$ nor osmotic treatments induced any significant changes in the REL of leaf discs.

Tissue respiration in leachate-treated water hyacinth leaf discs was assessed by measuring the reduction of TTC (Figure 2). Overall, $24 \mathrm{~h}$ and $48 \mathrm{~h}$ leachates both decreased the levels of TTC reduction by the leaf discs in a leachate concentration-dependent manner. The degree of decline in TTC reduction was generally similar in leaf discs treated with $24 \mathrm{~h}$ and $48 \mathrm{~h}$ leachates. At 5\%, both types of leachates decreased TTC reduction to about $40 \%$ below the control level.

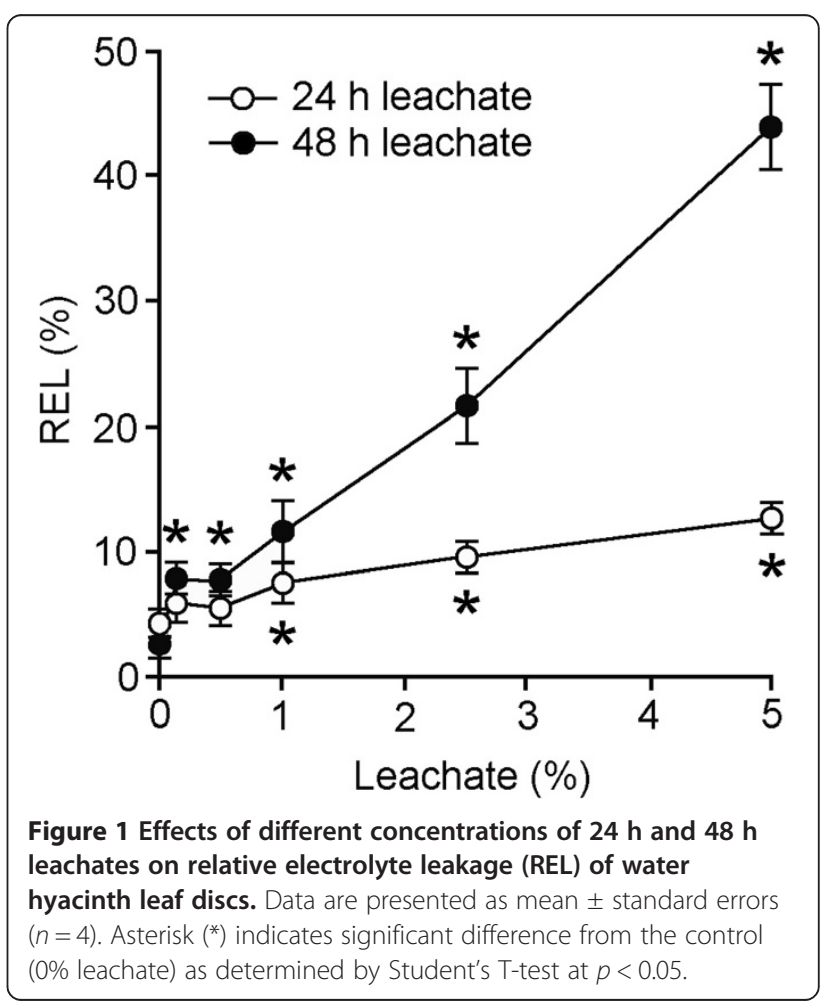




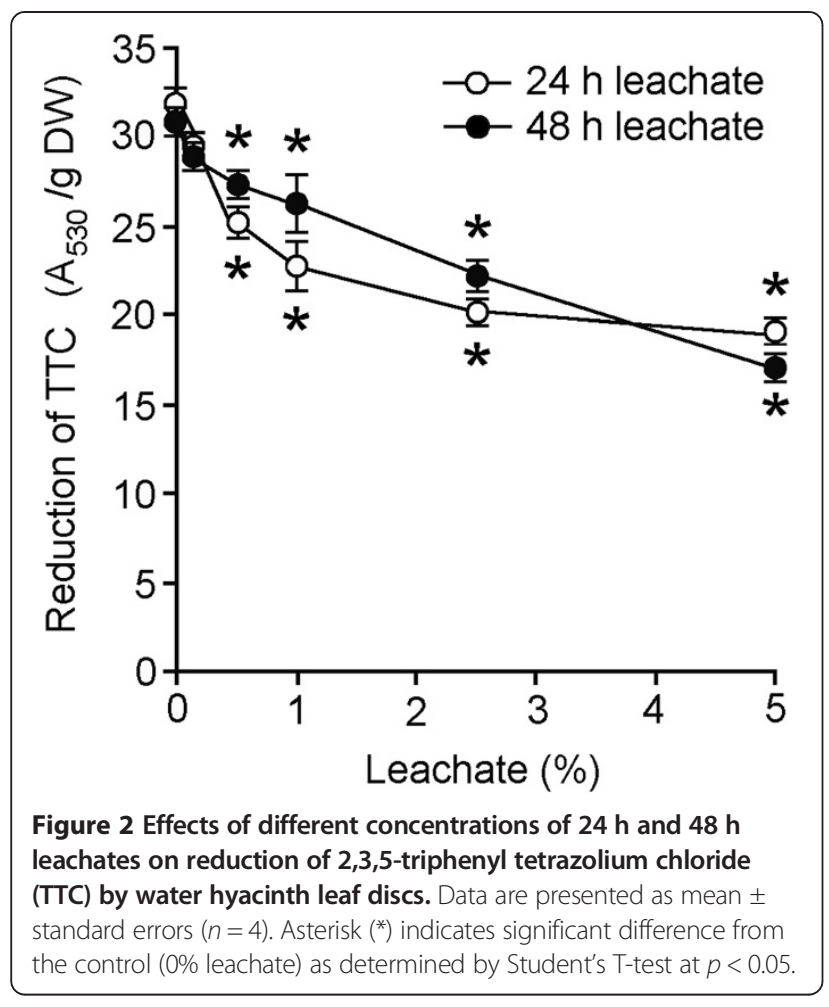

Treatment with $48 \mathrm{~h}$ leachate clearly increased ROS production in water hyacinth leaf discs. $\mathrm{H}_{2} \mathrm{O}_{2}$ content in the leaf discs increased in a leachate concentrationdependent manner (Figure 3). At 1, 2.5, and 5\% leachate concentrations, $\mathrm{H}_{2} \mathrm{O}_{2}$ content in the leaf tissues increased to 1.5-, 2.1- and 2.4-fold higher than the control level. In addition, enhanced production of $\mathrm{O}_{2}{ }^{\bullet-}$ was also detected in leaf discs treated with 2.5 and $5 \% 48$ h leachates (Figure 4).

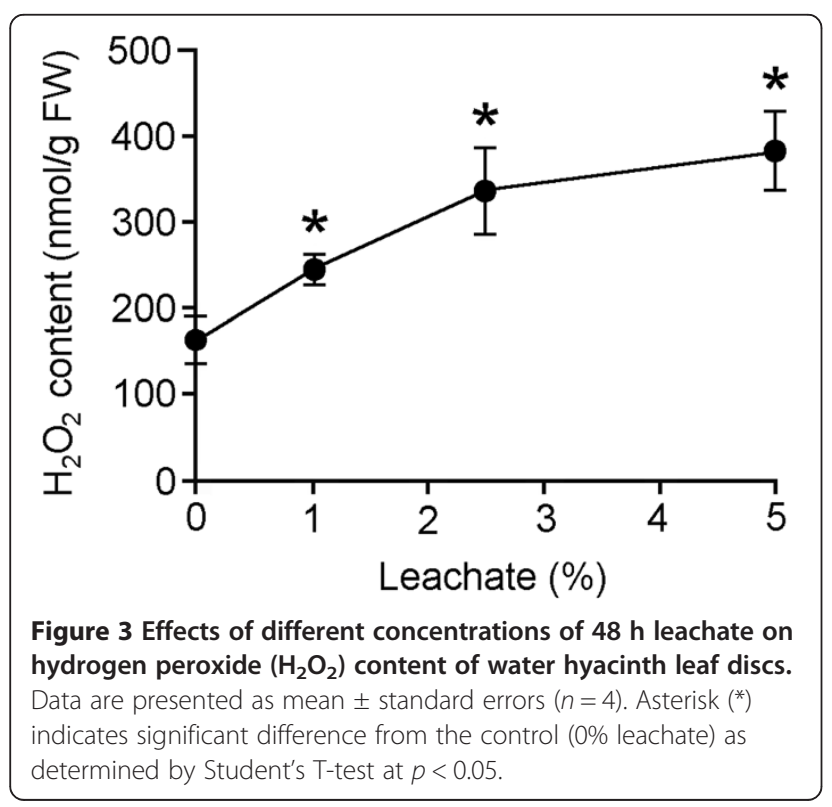

CAT specific activities were repressed in water hyacinth leaf tissues treated with $48 \mathrm{~h}$ leachate (Figure 5). At 1, 2.5, and 5\% leachate concentrations, CAT specific activities were inhibited by 43,33 , and $37 \%$ when compared with the control. Likewise, APX specific activities were inhibited in water hyacinth leaf tissues treated with $48 \mathrm{~h}$ leachate (Figure 6). In leaf discs treated with 1, 2.5, and $5 \%$ leachates, APX specific activities were progressively reduced by 11,28 , and $43 \%$ when compared with the control.

Phytochemical analysis found that the phenolic contents of $48 \mathrm{~h}$ leachate were overall about 2.8-fold higher compared with $24 \mathrm{~h}$ leachate (Table 1). Mimosine content in the $48 \mathrm{~h}$ leachate was 3.3-fold higher compared with the $24 \mathrm{~h}$ leachate. Correlation analysis between phytochemical contents of $L$. leucocephala leachates and REL values of leachate-treated leaf discs revealed high $\mathrm{R}^{2}$ values $\left(\mathrm{R}^{2}=0.94, p<0.05\right)$ (Table 2$)$. By contrast, moderate $\mathrm{R}^{2}$ values $\left(\mathrm{R}^{2}=0.51-0.55, p<0.05\right)$ were obtained between phytochemical contents of leachates and TTC reduction of leachate-treated leaf discs.

\section{Discussion}

Leucaena leucocephala is a well-studied allelopathic plant (John and Narwal, 2003). However, little is known about the phytotoxicity of $L$. leucocephala against aquatic weeds. In this study, we investigated effects of $L$. leucocephala leachate against water hyacinth leaf. Our findings demonstrated the potential of L. leucocephala as a bioherbicidal agent against water hyacinth.

Our REL results indicate that plasma membrane functions of water hyacinth leaf cells were disrupted by leachates of fresh leaves of L. leucocephala. REL assay is a sensitive test for the identification of allelochemicals, herbicides, or other compounds that destabilise cellular membranes (Dayan et al., 2000; Hoagland and Williams,

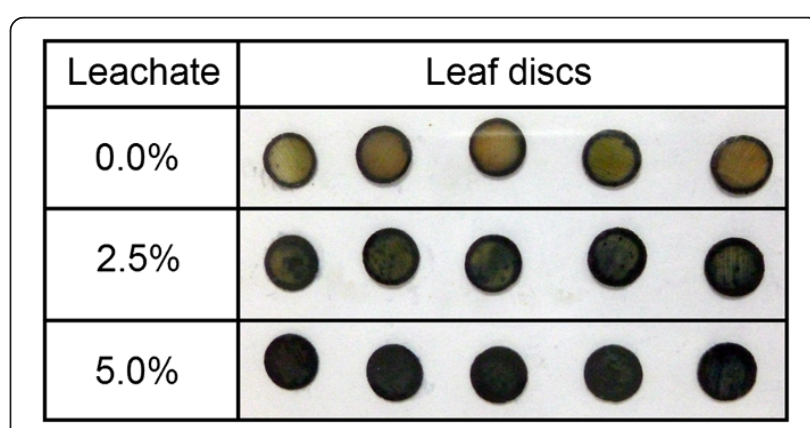

Figure 4 In situ tissue localisation of superoxide generation in water hyacinth leaf discs treated with $48 \mathrm{~h}$ leachate at different concentrations. Formation of dark blue spots all over the leaf discs treated with 2.5 and $5 \%$ leachates indicate greater levels of superoxide production compared with control leaf discs treated with deionised water (0\% leachate). 


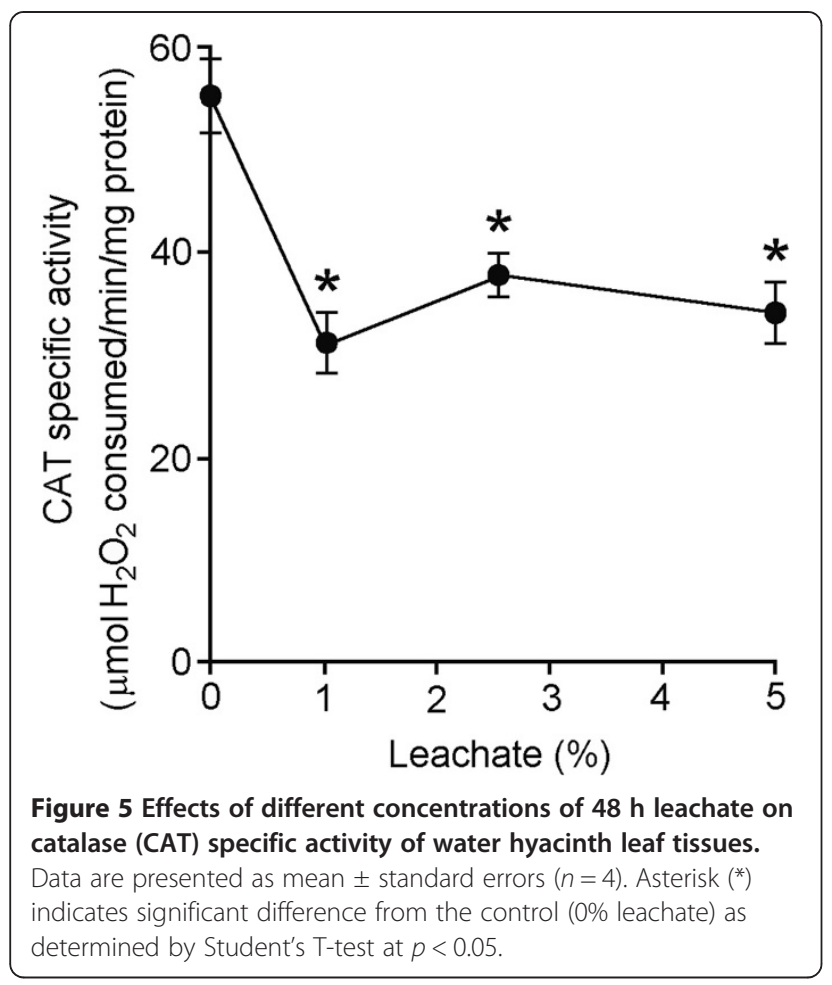

2004). Enhanced REL is also an indicator of cell death induction (Vidal et al., 2007; Luo et al., 2010; Mur et al., 2012). Hence, our findings clearly demonstrated the deleterious effects of $L$. leucocephala leachate on water hyacinth leaf tissues.

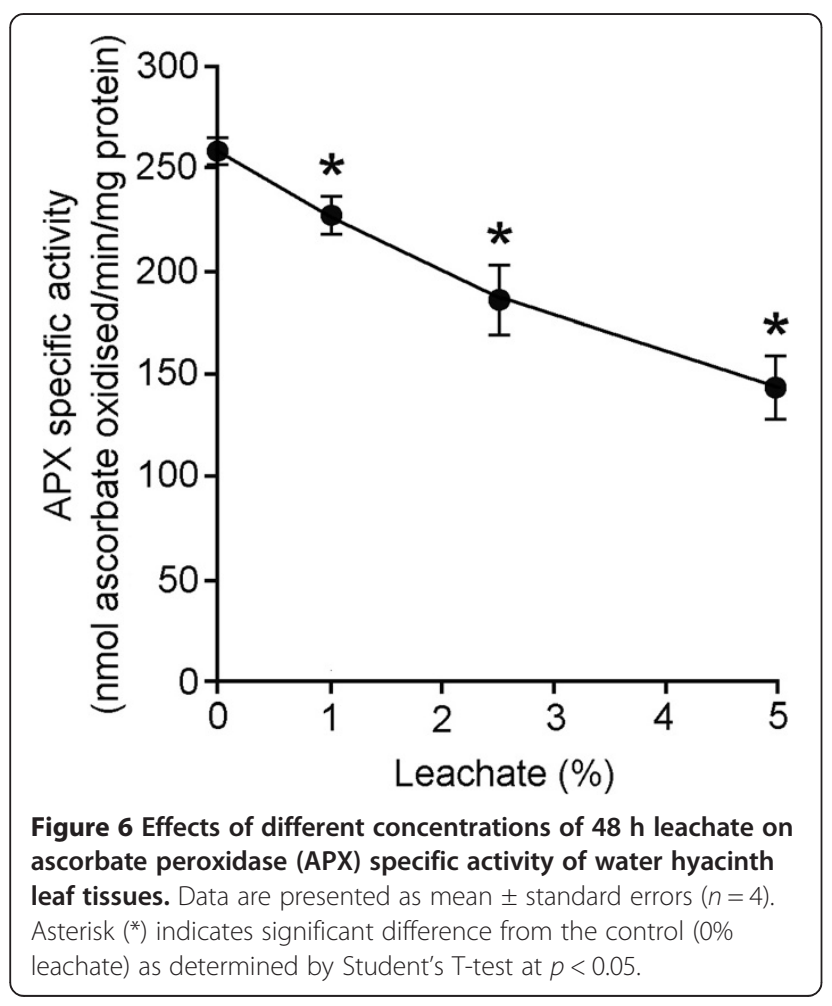

Table 1 Phytochemical contents of $5 \%$ leachate of $L$. leucocephala leaves

\begin{tabular}{ccccc}
\hline Leachate & $\begin{array}{c}\text { Total } \\
\text { polyphenols } \\
\text { (mg GAE/mL) }\end{array}$ & $\begin{array}{c}\text { Total } \\
\text { flavonoids } \\
(\mathbf{m g ~ Q E} / \mathrm{mL})\end{array}$ & $\begin{array}{c}\text { Total } \\
\text { hydroxycinnamic } \\
\text { acids } \\
\text { (mg CAE/mL) }\end{array}$ & $\begin{array}{c}\text { Mimosine } \\
(\mathbf{m g} / \mathbf{m L})\end{array}$ \\
\hline $24 \mathrm{~h}$ & $0.49 \pm 0.01$ & $0.52 \pm 0.01$ & $0.13 \pm 0.01$ & $0.28 \pm 0.00$ \\
$48 \mathrm{~h}$ & $1.31 \pm 0.02$ & $1.45 \pm 0.03$ & $0.36 \pm 0.01$ & $0.91 \pm 0.04$
\end{tabular}

Data are means \pm SE $(n=3)$. The values for $48 \mathrm{~h}$ leachate were all significantly different from those of the $24 \mathrm{~h}$ leachate according to Student's $\mathrm{T}$ test at $p<0.05$.

The loss of membrane stability in the leachate-treated leaf discs can be attributed to the phytotoxic chemical constituents in the leachates. Several lines of evidence support this proposal. Firstly, our control experiments eliminated the possibilities that the increased membrane permeability in the leachate-treated leaf discs was due to $\mathrm{pH}$ or osmotic effects of the leachates. Secondly, the higher phenolic and mimosine contents in the $48 \mathrm{~h}$ leachate relative to $24 \mathrm{~h}$ leachate paralleled the greater effects of the $48 \mathrm{~h}$ leachate on REL. Thirdly, our correlative analysis revealed that more than $90 \%$ of variation in REL may be accounted for by changes in the phytochemical contents measured. Finally, our findings are consistent with earlier reports of hydroxycinnamic acids, flavonoids and mimosine being phytotoxins in $L$. leucocephala (Chou and Kuo, 1986; John and Narwal, 2003; Chou, 2010).

In addition to loss of membrane integrity, decline in mitochondrial respiration activities was observed in the leachate-treated leaf tissues. Quercetin and 18 other flavonoids have been identified in the leaves of $L$. leucocephala (John and Narwal, 2003). Allelopathic flavonoids are known to act as inhibitors of the electron transport chain in the inner mitochondrial membrane (Einhellig, 2004). Mimosine, on the other hand, can cause mitochondrial dysfunction through rapid depolarisation of mitochondrial membranes in animal cells (Hallak et al., 2008). Hence, compromised dark respiration in the leachate-treated leaf discs may be attributed to the presence of flavonoids and/or mimosine which we detected in the leachate. Tissue respiration of leachatetreated leaf discs, nevertheless, correlated only moderately

Table 2 Correlation between phytochemical contents of L. leucocephala leachates and REL and TTC reduction of leachate-treated water hyacinth leaf tissues

\begin{tabular}{cccc}
\hline \multirow{2}{*}{ Parameters } & \multicolumn{3}{c}{ Correlation of determination $\left(\mathbf{R}^{2}\right)$} \\
\cline { 2 - 4 } & $\begin{array}{c}\text { Total } \\
\text { flavonoids }\end{array}$ & $\begin{array}{c}\text { Total hydroxycinnamic } \\
\text { acids }\end{array}$ & Mimosine \\
\hline REL & 0.943 & 0.943 & 0.942 \\
$\begin{array}{c}\text { TC } \\
\text { reduction }\end{array}$ & 0.507 & 0.554 & 0.512 \\
\hline
\end{tabular}

$\mathrm{R}^{2}$ values presented were all statistically significant $(p<0.05)$. 
with the phenolic and mimosine contents of the leachate. This implies that respiratory inhibition may not be the primary mechanism in the phytotoxicity of L. leucocephala leachate.

Maintenance of plant membrane functions is an energy-demanding process. However, the lack of close correspondence between our REL and respiration data implies that disruption in energy metabolism alone could not fully explain the perturbations of plasma membrane functions in the leachate-treated leaf discs. ROS, through their peroxidative action on membrane lipids, were likely a key contributor to the loss of membrane integrity in the leachate-treated water hyacinth leaf discs. Some effects on the leaf cell membranes could also be due to the direct actions of phenolic constituents in the leachate. Cinnamic and benzoic acid derivatives, for example, can directly alter membrane proteins, resulting in structural changes in plasma membranes and consequently an increase in non-specific ion efflux (Einhellig, 2004).

In this study, enhanced ROS production coincided with repression of CAT and APX activities in the leachate-treated water hyacinth leaf tissues. Our findings suggest that the L. leucocephala leachate may have rendered the water hyacinth leaf tissues vulnerable to oxidative injury by direct inhibition of antioxidant enzymes. This is plausible considering that mimosine, which we detected in the leachate, can inhibit catalase and peroxidases in leaf and root tissues (Prasad and Subhashini, 1994; Andrade et al., 2008). Furthermore, phenolic compounds such as gallic and caffeic acids can directly induce cellular ROS formation (Isuzugawa et al., 2001; Singh et al., 2009). Hence, the potential role of mimosine in inducing oxidative stress in the leachate-treated leaf discs was possibly exacerbated by phenolic allelochemicals in the leachate.

The practical application of using L. leucocephala to control water hyacinth requires further investigations. As L. leucocephala is a terrestrial species, its use to control water hyacinth may entail foliar spraying of leachates or extracts of L. leucocephala over a water hyacinth colony. Foliar spraying of Lantana camara leaf extract has been shown to suppress leaf bud emergence in water hyacinth and induce leaf tissue decay (Zheng et al., 2006). Hence, foliar spraying of L. leucocephala leachates or extracts may be an effective means to control water hyacinth plants in the field, although this must be confirmed in future experiments. The addition of dried powder of Coleus amboinicus leaves into water has been demonstrated to cause the death of water hyacinth plants (Kathiresan, RM 2000). Thus, an alternative to foliar spraying is by adding L. leucocephala leaf material directly into a water hyacinth-infested water body and allowing it to decompose. In any case, the potential effects of L. leucocephala leachate, extract or leaf material on other organisms in the water body should be considered when assessing the feasibility of using $L$. leucocephala as a bioherbicidal agent to control water hyacinth.

\section{Conclusion}

In conclusion, L. leucocephala leachate effectively attenuated plasma membrane functions, tissue respiration and antioxidant defence of the water hyacinth leaf tissues. Analyses carried out suggest that multiple phytotoxic compounds in the leachate may be acting in concert to compromise multiple target sites at the cellular level. More detailed biochemical and molecular studies are desired to further elucidate the modes of action of the leachate on specific target sites. Our study has demonstrated the bioherbicidal potential of L. leucocephala leachate on water hyacinth leaf discs under in vitro conditions. Future investigations using a whole-plant assay are required to confirm if $L$. leucocephala leachate has similar effects on intact water hyacinth plants under more natural conditions.

\section{Competing interests}

The authors declare that they have no competing interests.

\section{Authors' contributions}

C-TT and W-FC designed the experiment, carried out data analyses, and drafted the manuscript. O-PW, C-PS and O-KF carried out the experimental analyses. All authors read and approved the final manuscript.

\section{Acknowledgements}

The financial support from Universiti Tunku Abdul Rahman for the conduct of the research is gratefully acknowledged.

Received: 5 December 2012 Accepted: 27 March 2013

Published: 21 August 2013

\section{References}

Andrade AB, Ferrarese MLL, Teixeira AF, Ferrarese-Filho O (2008) Mimosineinhibited soybean (Glycine max) root growth, lignification and related enzymes. Allelopath J 21:145-154

Bingham FT, Strong JE, Rhoades JD, Keren R (1987) Effects of salinity and varying boron concentrations on boron uptake and growth of wheat. Plant Soil 97:345-351

Bradford MM (1976) A rapid and sensitive method for the quantitation of microgram quantities of protein utilizing the principle of protein dye binding. Anal Biochem 72:248-254

Chai TT, Wong FC (2012) Antioxidant properties of aqueous extracts of Selaginella willdenowii. J Med Plants Res 6:1289-1296

Chou CH (2010) Role of allelopathy in sustainable agriculture: Use of allelochemicals as naturally occurring bio-agrochemicals. Allelopath J 25:3-16

Chou CK, Kuo YL (1986) Allelopathic research of subtropical vegetation in Taiwan. III. Allelopathic exclusion of understory by Leucaena leucocephala (Lam.) de Wit. J Chem Ecol 12:1431-1448

Dayan FE, Romagni JG, Duke SO (2000) Investigating the mode of action of natural phytotoxins. J Chem Ecol 26:2079-2094

Dhindsa RS, Plumb-dhindsa P, Thorpe TA (1981) Leaf senescence: correlated with increased levels of membrane permeability and lipid peroxidation, and decreased levels of superoxide dismutase and catalase. J Exp Bot 32:93-101

Dutilleul C, Garmier M, Noctor G, Mathieu C, Chétrit P, Foyer CH, De Paepe R (2003) Leaf mitochondria modulate whole cell redox homeostasis, set antioxidant capacity, and determine stress resistance through altered signaling and diurnal regulation. Plant Cell 15:1212-1226

Einhellig FA (2004) Chapter 11. Mode of Allelochemical Action of Phenolic Compounds. In: Macías FA, Galindo JCG, Molinillo JMG, Cutler HG (eds) 
Allelopathy: Chemistry and mode of action of allelochemicals. CRC Press, Boca Raton, Florida, pp 217-238

Gniazdowska A, Bogatek R (2005) Allelopathic interactions between plants: multi site action of allelochemicals. Acta Physiol Plant 27:395-407

Hallak M, Vazana L, Shpilberg O, Levy I, Mazar J, Nathan I (2008) A molecular mechanism for mimosine-induced apoptosis involving oxidative stress and mitochondrial activation. Apoptosis 13:147-155

Hoagland RE, Williams RD (2004) Bioassays - Useful tools for the study of allelopathy. In: Macias FA, Galindo JCG, Molinillo JMG, Cutler HG (eds) Allelopathy: Chemistry and Mode of Action of Allelochemicals. CRC Press, Boca Raton, Florida, pp 315-351

Hong NH, Xuan TD, Eiji T, Hiroyuki T, Mitsuhiro M, Khanh TD (2003) Screening for allelopathic potential of higher plants from Southeast Asia. Crop Protect 22:829-836

Iftikhar Hussain M, Gonzalez-Rodriguez L, Reigosa MJ (2008) Germination and growth response of four plant species to different allelochemicals and herbicides. Allelopath J 22:101-110

Isuzugawa K, Inoue M, Ogihara Y (2001) Catalase contents in cells determine sensitivity to the apoptosis inducer gallic acid. Biol Pharm Bull 24:1022-1026

John J, Narwal SS (2003) Allelopathic plants. 9. Leucaena leucocephala (Lam.) de Wit. Allelopath J 12:13-36

Kathiresan RM (2000) Allelopathic potential of native plants against water hyacinth. Crop Protect 19:705-708

Kraus TE, Fletcher RA (1994) Paclobutrazol protects wheat seedlings from heat and paraquat injury: is detoxification of active oxygen involved? Plant Cell Physiol 35:45-52

Li ZH, Wang Q, Ruan X, Pan CD, Jiang DA (2010) Phenolics and plant allelopathy. Molecules 15:8933-8952

Luo H, Laluk K, Lai Z, Veronese P, Song F, Mengiste T (2010) The Arabidopsis Botrytis Susceptible1 Interactor defines a subclass of RING E3 ligases that regulate pathogen and stress responses. Plant Physiol 154:1766-1782

Malik A (2007) Environmental challenge vis a vis opportunity: the case of water hyacinth. Environ Int 33:122-138

Matkowski A, Tasarz P, Szypuła E (2008) Antioxidant activity of herb extracts from five medicinal plants from Lamiaceae, subfamily Lamioideae. J Med Plants Res 2:321-330

Mur LAJ, Sivakumaran A, Mandon J, Cristescu SM, Harren FJM, Hebelstrup KH (2012) Haemoglobin modulates salicylate and jasmonate/ethylene-mediated resistance mechanisms against pathogens. J Exp Bot 63:4375-4387

Nakano Y, Asada K (1981) Hydrogen peroxide is scavenged by ascorbate-specific peroxidase in spinach chloroplasts. Plant Cell Physiol 22:867-880

Pandey DK, Kauraw LP, Bhan VM (1993) Inhibitory effect of parthenium (Parthenium hysterophorus L.) residue on growth of water hyacinth (Eichhornia crassipes Mart Solms.). I. Effects of leaf residue. J Chem Ecol 19:2651-2662

Prasad MNV, Subhashini P (1994) Mimosine-inhibited seed germination, seedling growth, and enzymes of Oryza sativa L. J Chem Ecol 20:1689-1696

Raviv M, Blom TJ (2001) The effect of water availability and quality on photosynthesis and productivity of soilless-grown cut roses - A Review. Sci Hortic 88:257-276

Saxena MK (2000) Aqueous leachate of Lantana camara kills water hyacinth J Chem Ecol 26:2435-2447

Singh HP, Batish DR, Kohli RK (2003) Allelopathic interactions and allelochemicals: new possibilities for sustainable weed management. Crit Rev Plant Sc 22:239-311

Singh HP, Kaur S, Batish DR, Kohli RK (2009) Caffeic acid inhibits in vitro rooting in mung bean [Vigna radiata (L.) Wilczek] hypocotyls by inducing oxidative stress. Plant Growth Regul 57:21-30

Soedarjo M, Borthakur D (1996) Simple procedures to remove mimosine from young leaves, pods and seeds of Leucaena leucocephala used as food. Int J Food Sci Technol 31:97-103

Sosa L, Llanes A, Reinoso H, Reginato M, Luna V (2005) Osmotic and specific ion effects on the germination of Prosopis strombulifera. Ann Bot 96:261-267

Steponkus PL, Lanphear FO (1967) Refinement of the triphenyl tetrazolium chloride method of determining cold injury. Plant Physiol 42:1423-1426

Szczepanski AJ (1977) Allelopathy as a means of biological control of water weeds. Aquat Bot 3:193-197

Velikova V, Yordanov I, Edreva A (2000) Oxidative stress and some antioxidant systems in acid rain-treated bean plants: protective role of exogenous polyamines. Plant Sci 151:59-66
Vidal G, Ribas-Carbo M, Garmier M, Dubertret G, Rasmusson AG, Mathieu C, Foyer CH, De Paepe R (2007) Lack of respiratory chain complex I impairs alternative oxidase engagement and modulates redox signaling during elicitor-induced cell death in tobacco. Plant Cell 19:640-655

Weir TL, Park S-W, Vivanco JM (2004) Biochemical and physiological mechanisms mediated by allelochemicals. Curr Opin Plant Biol 7:472-479

Zheng $\mathrm{H}-\mathrm{Q}$, Wei N, Wang L-F, He P (2006) Effects of Lantana camara leaf extract on the activity of superoxide dismutase and accumulation of $\mathrm{H}_{2} \mathrm{O}_{2}$ in water hyacinth leaf. J Plant Physiol Mol Biol 32:184-189

doi:10.1186/1999-3110-54-8

Cite this article as: Chai et al: Leucaena leucocephala leachate compromised membrane integrity, respiration and antioxidative defence of water hyacinth leaf tissues. Botanical Studies 2013 54:8.

\section{Submit your manuscript to a SpringerOpen ${ }^{\circ}$ journal and benefit from:}

- Convenient online submission

- Rigorous peer review

- Immediate publication on acceptance

- Open access: articles freely available online

- High visibility within the field

- Retaining the copyright to your article

Submit your next manuscript at $\gg$ springeropen.com 